\title{
The Effect of Peanut Skin Compost Mix Variaries on Planting Media on the Growth of Dendrobium $S p$
}

\author{
Nur Rokhimah Hanik ${ }^{1 *}$, Sri Harsono ${ }^{1}$, Ratna Dewi Eskundari ${ }^{1}$ \\ ${ }^{1}$ Program Studi Pendidikan Biologi, Universitas Veteran Bangun Nusantara, Sukoharjo, Indonesia
}

\author{
Article History \\ Received : February $02^{\text {th }}, 2021$ \\ Revised : February $15^{\text {th }}, 2021$ \\ Accepted : February $20^{\text {th }}, 2021$ \\ Published : March $04^{\text {th }}, 2021$ \\ *Corresponding Author: \\ Nur Rokhimah Hanik, \\ Universitas Veteran Bangun \\ Nusantarai, Sukoharjo, \\ Indonesia; \\ Email:nurhanik03@gmail.com
}

\begin{abstract}
Ferns are a growing medium for orchids that are starting to be protected so that their availability is very limited and quite expensive, therefore a solution is needed to reduce maintenance costs by utilizing peanut shell compost as a mixture of media. Peanut shell compost can act as a medium and fertilizer. The purpose of this study is: 1 . To determine the effect of various peanut shell compost mixtures in growing media on Dendrobium orchid growth. 2. To determine the best composition of peanut shell compost mixture for Dendrobium orchid growth. The results of this study serve as information material for Dendrobium orchid collectors and entrepreneurs about the effect of various peanut shell compost mixtures in growing media on the growth of Dendrobium orchids, as well as a reference material for further research related to efforts to improve Dendrobium orchid cultivation, especially the use of peanut shells as a medium. Grow as well as compost to increase the growth of Dendrobium orchids. The research period was started from July 2020 to December 2020. The research object was a 12 month old Dendrobium orchid, the research location was in Gabahan RT 05 RW 12 Jombor Bendosari Sukoharjo. Simple randomized research design with four treatments. Treatment A / K.0 of fern growing media without peanut shell compost, treatment B / K.1 / 2 of fern media mixed with compost with a ratio of 1: 1 , treatment C / K.1 / 3 media fern mixed with peanut shell compost with a ratio 2/3: $1 / 3$, and treatment C / K.1 / 4 media of fern mixed with peanut shell compost in the ratio 3/4: 1/4. Data were measured after 12 weeks from planting. Data analysis with Variance Test (Anava test) and advanced Duncan Multiple Range Test (DMRT). From the research it can be concluded that the variation of the peanut shell compost mixture in the growing medium has a significant effect on the growth of Dendrobium orchids on four (4) observed growth parameters (Leaf Length, Number of Leaves, Leaf Area, and Wet Weight. Moderate for the Number of tillers. There was a difference in effect, although this difference was not significant. And the treatment of compost mixture B / K.1 / 2 or with a ratio of 1: 1 gave the best effect on all observed growth parameters (Leaf Length, Number of Leaves, Leaf Area, Number of Tillers, and Gross weight. There is still a need to develop further research on peanut shell compost as a mixture for growing media, because in addition to reducing costs for growing media it can also reduce costs for purchasing fertilizer, because peanut shell compost contains a lot of $\mathrm{N}$, $\mathrm{P}$, and $\mathrm{K}$ elements. soil on growing media can reduce maintenance costs.
\end{abstract}

Keywords: Peanut shell compost, growth, and orchids of Dendrobium sp

\section{Pendahuluan}

Anggrek Dendrobium adalah salah satu genus anggrek favorit bagi pecinta banyak anggrek, karena penampilanya yang sangat beragam, indah, dan tahan lama (Tuhuteru, at al., 2012). Menurut Departemen Pertanian (2005), anggrek potong yang dominan disukai masyarakat adalah jenis Dendrobium, yaitu 
sebanyak 34\%. Selain itu anggrek Dendrobium ini mampu beradaptasi dengan berbagai kondisi lingkungan tumbuh, memiliki kemampuan menerima langsung sinar matahari tanpa membahayakan dirinya dan selama musim dingin, Dendrobium membutuhkan air yang sangat sedikit. Jenis angrek ini juga merupakan salah satu jenis anggrek yang banyak disukai konsumen, karena bunganya tahan lama dan tidak mudah rontok, dengan bentuk dan warna bunga yang sangat bervariasi (Tuhuteru, at al., 2012).

Pada saat ini pengusahaan dan kolektor anggrek akan menghadapi masalah terutama pada negara dimana ketersediaan media tumbuh semakin sulit serta mahal harganya. Oleh karena itu para pencinta anggrek selalu mencari medium tumbuh yang baru. Medium yang diperlukan adalah medium yang dapat menyimpan air dan unsur hara serta melepaskannya pada perakaran secara perlahanlahan, tidak mudah melapuk, tersedianya udara yang cukup bagi perakaran, mudah didapat dan relatif murah harganya. (Indrasti, N S dan Rio Reyno Elia. 2004).

Pemilihan media tumbuh sangatlah penting, karena sangat mendukung untuk kesuburan dan pertumbuhan anggrek secara maksimal. Hal yang harus diperhatikan dalam pemilihan media anggrek adalah aerasi udara, kelembapan, daya menahan air, tingkat serangan jamur, dan hama penyakit (Setiawan dan Setiawan, 2004). Beberapa bahan yang dapat digunakan sebagai media tanam anggrek adalah pakis, sabut kelapa, arang, dan lumut (Kartana, 2017). Sedang menurut Setiawan dan Setiawan (2004) media anggrek antara lain adalah pakis, sangat mudah menyimpan air, banyak mengandung nutrisi unsur $\mathrm{Mg}$, tidak mudah berjamur). media pakis mampu menyiapkan habitat yang baik untuk pertumbuhan akar, karena lingkungan banyak mengandung oksigen, aerasi baik, tidak mudah melapuk, dan memiliki kandungan zat hara organik. (Herliana, O. et al 2018).

Pakis merupakan media tanam yang umum digunakan dalam budidaya anggrek, namun permintaan pakis yang semakin banyak akan meningkatkan harga jual dan penggadaan pakis menjadi terbatas.( Tri Dewi Andalasari, Yafisham, dan Nuraini. 2014), kedepannya harga pakis akan semakin mahal. Apalagi sekarang jenis tumbuhan pakis (jenis Palm) mulai dilindungi (Peraturan Menteri Lingkungan Hidup Dan Kehutanan Republik Indonesia

Nomor P.92/Menlhk/
Setjen/Kum.1/8/2018) dan jenis tumbuhan paku pohon yang termasuk dalam marga Cibotium, Cyathea dan Dicksonia. Ketiganya merupakan jenis tumbuhan paku yang dilindungi dan termasuk dalam Appendix II CITES (Convention on International Trade) Hanum, Siti Fatimah et al (2014) Bagi pecinta, kolektor, dan penjual anggrek kedepan pastilah biaya perawatan anggrek Dendrobium akan meningkat.

Menyadari akan hal tersebut maka Tim peneliti mencoba memberikan solusi dengan memanfaatan limbah kulit kacang tanah sebagai media tumbuh anggrek. Dengan mengadakan penelitian (tahun 2019) tentang pemanfaatan kulit kacang sebagai media tumbuh anggrek bulan Phalaenopsis amabilis. Dengan membandingkan pertumbuhan anggrek bulan tersebut pada media pakis, campuran pakis dan kulit kacang tanah, serta media kulit kacang tanah, namun hasilnya menyimpulkan bahwa antara media pakis, kulit kacang tanah, dan campuran pakis dengan kulit kacang tanah tidak memberikan pengaruh yang nyata pada pertumbuhan anggrek bulan Phalaenopsis pada berbagai variabel (jumlah daun, luas, daun, panjang dan lebar daun, jumlah akar, rata-rata panjag akar, serta betar basah) (Hanik. NR, et al 2020). Dari hasil tersebut peneliti ingin melanjutkan penelitian dengan membuat kulit kacang tanah yang digunakan sebagai campuran media dibuat kompos terlebih dahulu sehingga sifat kulit kacang tanah akan menjadi lunak dan terurai menjadi bahan organik. Karena dari penelitian sebelumnya (Sutanto dan Setiawan dalam Dahlan dan Darmansyah, 2011) menyatakan bahwa, pengaruh pemberian pupuk limbah kacang tanah, antara lain: 1. Memudahkan penyerapan air hujan 2 . Memperbaiki kamampuan tanah dalam mengikat air 3. Mengurangi erosi 4. Memberikan lingkungan tumbuh yang baik bagi kecambah biji dan akar serta 5. Mengandung unsur hara bagi tanaman. Selanjutnya oleh Setiawan (2005) dijelaskan bahwa pupuk buatan limbah kacang tanah mengandung unsur hara makro yakni N, P, dan K. Ketiga unsur inilah yang paling banyak dibutuhkan oleh tanaman, karena masing-masing mempunyai fungsi bagi pertumbuhan tanaman. Kulit kacang mengandung banyak mineral, seperti kalsium, fosfor, potasium, iron, sodium, mangan, zink. Yang sangat bermanfaat bagi tanaman (Nisrina, 2013). Sedang menurut Irdhawati et al. (2016) dan .Trivedi, N S, et al (2019) Komposisi kulit kacang tanah terdiri dari 9,5\% air, $3,6 \%$ abu, $8,4 \%$ protein, $63,5 \%$ selulosa, $13,2 \%$ 
lignin, dan 1,8\% lemak. Selain itu dari hasil penelitian Iga Noviarti, et al 2015) menyimpulkan bahwa, pemberian bokashi atau pupuk kompos kulit kacang tanah dapat meningkatkan produksi buncis yaitu pada jumlah polong buncis.

Sampel tanaman anggrek yang digunakan adalah Dendrobium karena perupakan anggrek simpodial yang perawatan dan pertumbuhannya sangat mudah diamati, tahan terhadap panas dan membutuhkan air sedikit, serta mampu beradaptasi dengan berbagai kondisi lingkungan tumbuh. Selain itu cara perawatannya mudah, anggrek ini juga lebih cepat berbunga (Tuhuteru, at al., 2012). Media yang digunakan dalam penelitian ini adalah akar pakis, karena menurut hasil penelitian Nur Rokhimah Hanik ( 2007) media pakis paling berpengaruh terhadap pertumbuhan anggrek bulan Phalaenopsis amabilis dibanding media sabut kelapa dan Moss, akar pakis mengandung unsur $\mathrm{Mg}$ yang sangat diperlukan untuk pembentukan klorofil. Selain itu menurut Tarigan, H M (2009) media pakis baik untuk pertumbuhan anggrek Oncidium golden Shower. Keunggulan media pakis dibandingkan dengan media tanam yang lain diduga media pakis memiliki kriteria yang baik bagi pertumbuhan tanaman anggrek diantaranya pakis mampu mengikat dan menyimpan air dengan baik, memiliki aerasi dan draenasi baik, melapuk secara perlahan dan mengandung unsur hara yang diperlukan bagi tanaman anggrek (Widiastoety, 2004).

Adapun tujuan yang diajukan dalam penelitian ini adalah: 1 . Untuk mengetahui pengaruh variasi campuran kompos kulit kacang tanah pada media tumbuh terhadap pertumbuhan anggrek Dendrobium 2. Untuk mengetahui komposisi campuran kompos kulit kacang tanah yang paling baik untuk pertumbuhan anggrek Dendrobium $s p$. Hasil penelitian ini sebagai bahan informasi bagi kolektor dan pengusaha anggrek bulan tentang pengaruh variasi campuran kompos kulit kacang tanah pada media tumbuh terhadap pertumbuhan anggrek Dendrobium sp, serta sebagai bahan rujukan bagi penelitian selanjutnya yang berkaitan dengan upaya perbaikan budidaya anggrek bulan khususnya pemanfaatan kompos kulit kacang tanah sebagai campuran media tumbuh anggrek Dendrobium $s p$.

\section{Bahan dan Metode}

\section{Lokasi dan Waktu Penelitian}

Penelitian untuk pengambilan data dilaksanakan di dalam rak berparanet paranet $75 \%$, selama 2.5 bulan (26 September sampai 19 Desember 2020) di Gabahan Baru RT 05 RW 12 Jombor Bendosari Sukoharjo dengan ketinggian tempat \pm 86 meter dari permukaan laut dan pada kisaran suhu $24^{\circ} \mathrm{C}-30,5^{\circ} \mathrm{C}$

\section{Bahan dan Alat}

Adapun bahan dan alat yang digunakan adalah: Bibit anggrek Dendrobium sp umur 12 bulan. Start Vitamin B-1 dan fungisida Dithane M45, Media tanam anggrek berupa pakis halus, Kompos kulit kacang tanah, Rak kayu dengan paranet $75 \%$ dan Pot plastik ukuran kecil, sprayer, penggaris (meteran), timbangan digital, sendok makan, corong pastik, gelas ukur, leaf area meter.

\section{Metode Penelitian}

Penelitian ini menggunakan Rancangan Acak Sederhana, dengan 4 perlakuan ;

Perlakuan A: penanaman anggrek dengan media campuran batang arang untuk 1/4 bagian bawah pot, dan 3/4 Pakis semua dipotong kecil-kecil $\pm 1 \mathrm{~cm}$, sebanyak 10 pot

Perlakuan B: penanaman anggrek dengan media campuran batang arang untuk 1/4 bagian bawah pot dan 1 bagian Pakis dicampur kompos kulit kacang tanah 1 bagian $(1 / 2: 1 / 2)$, sebanyak 10 pot .

Perlakuan C: penanaman anggrek dengan media campuran batang arang untuk 1/4 bagian bawah pot dan $2 / 3$ bagian Pakis dicampur kompos kulit kacang tanah (1/ 3 bagian), sebanyak 10 pot.

Perlakuan D: penanaman anggrek dengan media campuran batang arang untukn 1 1/4 bagian pot dan 3/4 Paki s dicampur kompos kulit kacang tanah (1/4 bagian) , sebanyak 10 pot.

Variabel pertumbuhan yang diamati dalam penelitian ini meliputi : panjang daun, jumlah daun, luas daun, jumlah anakan, serta berat basah (Sitompul, S. M dan Guritno, Bambang. 1995) data diukur pada akhir penanaman yaitu setelah 12 minggu. Pemberian vitamin B1 diberikan seminggu sekali pada hari Sabtu dan penyemprotan jamur dengan Dewtan M45 setiap hari Minggu. Tehnik analisis data menggunakan uji Ragam anava Satu Jalur dengan taraf nyata 5\% dan 1\%. Jika antar 
Hanik, NR. et al., (2021). Jurnal Biologi Tropis, 21 (1): 237 - 247

DOI: http://dx.doi.org/10.29303/ibt.v21i1.2465

perlakuan terdapat pengaruh nyata, maka analisis dilanjutkan dengan analisis Duncan Multiple Range Test (DMRT) (Anwar Hidayat, 2014).

\section{Tahapan Penelitian}

a. Menganalisis manfaat limbah kulit kacang tanah, kompos kulit kacang tanah, media tanam anggrek, dan pemupukan pada berbagai hasil penelitian tentang pertumbuhan tanaman khususnya anggrek.

b. Menganalisis jenis media yang telah ada dan yang paling baik untuk pertumbuhan anggrek Dendrobium sebagai media control dalam perlakuan. c. Menyiapkan perangkat /alat yang diperlukan untuk pencarian data penelitian, merencanakan waktu, tempat pelaksanaan, dan materi/pustaka

d. Pelaksanaan penelitian, pencarian data pengaruh media kulit kacang tanah pada pertumbuhan anggrek Dendrobium $s p$ (menanam anggrek dengan 4 variasi media, merawat dan mengamati pertumbuhannya, serta mengukur variabel setelah 12 minggu penanaman.

e. Menganalisis hasil penelitian dan pembuatan laporan

f. Menyimpulkan pengaruh variasi campuran kompos kulit kacang tanah pada media tumbuh terhadap pertumbuhan anggrek Dendrobium sp

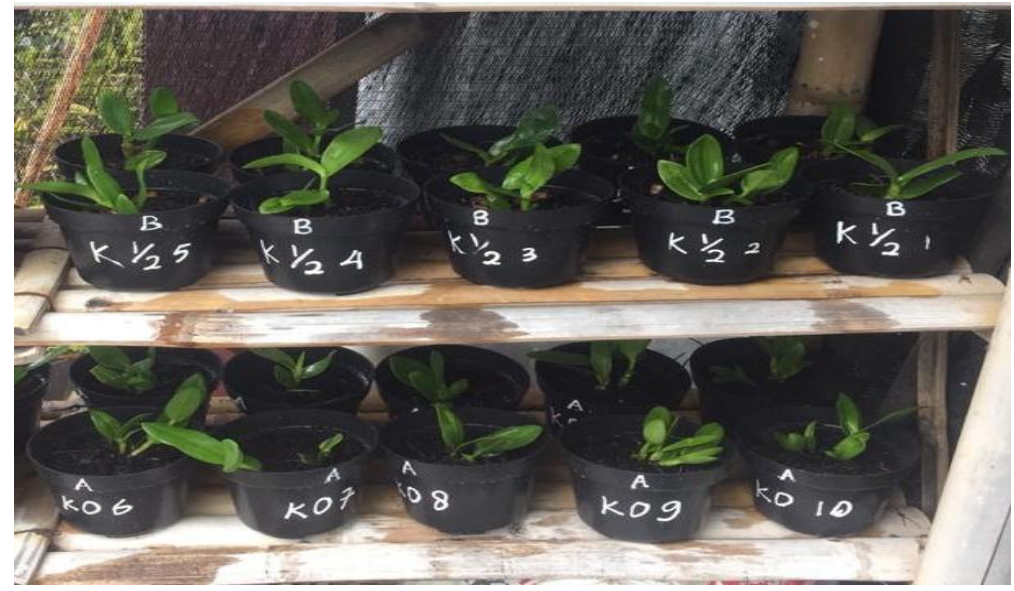

Gambar 1: Sampel anggrek dengan perlakuan A dan B

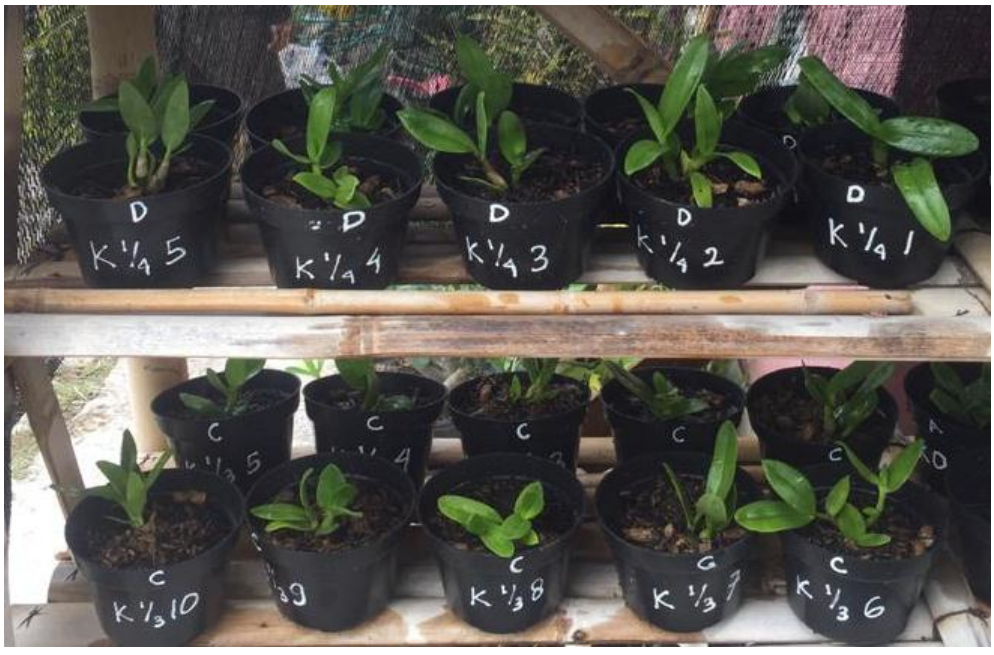

Gambar 1: Sampel anggrek dengan perlakuan C dan D 
Hanik, NR. et al., (2021). Jurnal Biologi Tropis, 21 (1): 237 - 247

DOI: http://dx.doi.org/10.29303/jbt.v21i1.2465

\section{Hasil dan Pembahasan}

Anggrek Dendrobium

Anggrek Dendrobium ditanam selama 12 minggu, kemudian dilakukan pengukuran terhadap 5 parameter pertumbuhan, yaitu Panjang Daun, Jumlah Daun, Luas Daun, Jumlah Anakan, serta Berat Basah tanaman. Kemudian data dianalisis dengan uji ragam ANAVA. Adapun hasil analisisnya sebagai berikut:

Tabel 1. Hasil ANAVA Panjang Daun, Jumlah Daun, Luas Daun, Jumlah Anakan, dan Berat Basah

\begin{tabular}{|l|r|r|r|r|c|}
\hline & \multicolumn{1}{|c|}{$\begin{array}{c}\text { Sum of } \\
\text { Squares }\end{array}$} & Df & Mean Square & F & Sig. \\
\hline Panjang Daun & 45,537 & 3 & 15,179 & 6,490 &, 001 \\
\hline Jumlah Daun & 63,200 & 3 & 21,067 & 5,448 &, 003 \\
\hline Luas Daun & 642,106 & 3 & 214,035 & 9,933 &, 000 \\
Jumlah Anakan & 0,005 & 3 & 0,167 & 0,291 & 0,831 \\
Berat Basah & 817,843 & 3 & 272,614 & 13,343 & 0,000 \\
\hline
\end{tabular}

Hasil Analisis Varian (ANOVA) untuk Panjang Daun, Jumlah Daun, Luas Daun, serta Berat Basah, nilai signifikansi < 0,05 , yang berarti terdapat perbedaan pengaruh yang signifikan pada variasi pemberian kompos kulit kacang tanah pada media tumbuh terhadap pertumbuhan Panjang Daun, Jumlah Daun, Luas Daun serta Berat Basah, sedangkan untuk Jumlah Anakan hasil Analisis Varian nilai signifikansi $>0,05$ yang berarti tidak ada perbedaan pengaruh yang signifikan pada variasi pemberian kompos kulit kacang tanah pada media tumbuh terhadap pertumbuhan Jumlah anakan.

Dari hasil uji lanjut DMRT (Duncun Multiple Rank Tes) untuk Panjang Daun terdapat perbedaan Panjang Daun pada perlakuan B/K.1/2 dengan perlakuan A/K.0, C/K.1/3, dan D/K.1/4. Sedangkan Panjang Daun pada perlakuan A/K.0, C/K.1/3, dan $\mathrm{D} / \mathrm{K} .1 / 4$ tidak terdapat perbedaan yang signifikan, untuk Jumlah Daun perlakuan B/K.1/2 tidak berbeda dengan perlakuan $\mathrm{C} / \mathrm{K} .1 / 3$, tetapi terdapat perbedaan dengan perlakuan A/K.0 dan perlakuan D/K.1/4, untuk Luas Daun terdapat perbedaan perlakuan B/K.1/2 dengan perlakuan A/K.0, C/K.1/3, dan D/K.1/4, tetapi antar perlakuan A/K.0, C/K.1/3 dan D/K.1/4 tidak terdapat perbedaan. Sedangkan Hasil uji DMRT pada perlakuan A/K.0, B/K.1/2, C/K.1/3, dan D/K.1/4 tidak terdapat perbedaan pada pertumbuhan Jumlah Anakan.

Pada hasil uji DMRT untuk Berat Basah terdapat perbedaan antara perlakuan $\mathrm{B} / \mathrm{K} .1 / 2$ dengan $\mathrm{C} / \mathrm{K} .1 / 3$, juga terdapat perbedaan dengan perlakuan D/K.1/4 dan A/K.0, namun perlakuan A/K.0 dengan D/K.1/4 tidak memberikan pengaruh yang berbeda pada pertumbuhan Berat Basah.

\section{Pembahasan}

\section{Panjang Daun}

Dari hasil Analisis Varian (ANAVA) terhadap pertumbuhan Panjang Daun anggrek Dendrobium setelah penanaman selama 12 minggu nilai signifikansi 0,001<0,05 dan hasil uji lanjut DMRT terdapat perbedaan Panjang Daun pada perlakuan B/K.1/2 dengan perlakuan A/K.0, C/K.1/3, dan D/K.1/4. Sedangkan Panjang Daun pada perlakuan A/K.0, C/K.1/3, dan D/K.1/4 secara matematik terdapat perbedaan meskipun secara statistik tidak berbeda secara yang signifikan. Perbedaan Panjang Daun terjadi kemungkinan karena kompos kulit kacang yang diberikan pada media tumbuh anggrek Dendrobium tersebut. Dan hal ini sesuai dengan hasil penelitian dari Iga Noviarti, Mulyati, dan Lince Meriko (2015), kulit kacang tanah digunakan sebagai pupuk Bokashi pada produksi tanaman Buncis (Phaseolus vulgaris L) dimana pemberian bokashi kulit kacang tanah dapat meningkatkan produksi buncis yaitu pada jumlah polong buncis.

Pengembangan Media Tumbuh Anggrek dengan Menggunakan Kompos oleh Indrasti Nastiti Siswidan Elia, dan Rio Reyno, 2004. Dengan membandingkan hasil analisis secara keseluruhan maka kombinasi perlakuan terbaik diperoleh pada penggunaan rasio campuran kompos dan tanah liat sebesar 2:2 atau perbandingan $1 / 2: 1 / 2$. Perlakuan B/K.1/2 hasil pertumbuhan terbaik pada Panjang Daun, $(10,57 \mathrm{~cm})$ dimana Panjang Daun merupakan indikator kesuburan tanaman dari hasil Fotosintesa, dan pada Fotosintesa sangat dibutuhkan nutrisi atau pupuk pada tanaman. Nitrogen berperan untuk 
sintesis protein untuk pertumbuhan tanaman termasuk pertumbuhan daun, bila tanaman kekurangan $\mathrm{N}$ menyebabkan pertumbuhan terhambat. Peran utama nitrogen bagi tanaman yaitu merangsang pertumbuhan seluruh tanaman terutama batang, cabang, dan daun. Pada pertumbuhan vegetatif tanaman yang ditunjukkan dengan pertambahan panjang, salah satu unsur hara yang berperan adalah nitrogen $(\mathrm{N})$. Nitrogen memacu pertumbuhan pada vase vegetatif terutama daun dan batang (Sayekti, R. S, at all. 2016), sehingga wajar jika perlakuan $\mathrm{B} / \mathrm{K} .1 / 2$ yang mengandung paling banyak unsur $\mathrm{N}, \mathrm{P}$, dan, $\mathrm{K}$ dapat menghasilkan pertumbuhan Panjang Daun paling baik, Setiawan (2005) menjelaskan bahwa pupuk buatan limbah kacang tanah mengandung unsur hara makro yakni $\mathrm{N}$, P, dan K. Ketiga unsur inilah yang paling banyak dibutuhkan oleh tanaman, karena masing-masing mempunyai fungsi bagi pertumbuhan tanaman. Kulit kacang mengandung banyak mineral, seperti kalsium, fosfor, potasium, iron, sodium, mangan, dan zink yang sangat bermanfaat bagi tanaman (Nisrina, 2013).

\section{Jumlah Daun}

Dari hasil Analisis Varian terhadap pertumbuhan Jumlah Daun anggrek Dendrobium setelah penanaman selama 12 minggu nilai signifikasni $0,003<0,05$ dan hasil uji lanjut DMRT terdapat perbedaan Panjang Daun pada perlakuan $\mathrm{B} / \mathrm{K} .1 / 2$ dengan perlakuan $\mathrm{A} / \mathrm{K} .0$, dan $\mathrm{D} / \mathrm{K} .1 / 4$, namun tidak terdapat perbedaan dengan perlakuan C/K.1/3. Perbedaan Panjang Daun ini terjadi kemungkinan karena kompos kulit kacang yang diberikan pada media tumbuh anggrek Dendrobium tersebut. Dan hal ini sesuai dengan hasil penelitian dari Iga Noviarti, Mulyati, dan Lince Meriko (2015), Kulit kacang tanah digunakan sebagai pupuk Bokashi pada produksi tanaman Buncis (Phaseolus vulgaris $L$ ) dimana pemberian bokashi kulit kacang tanah dapat meningkatkan produksi buncis yaitu pada jumlah polong buncis.

Jumlah Daun pada hasil penelitian ini terbaik pada perlakuan B/K.1/2 yaitu 10 helai, dan hasil ini sesuai dengan hasil penelitian (Sayekti, R. S, at all. 2016), bahwa antara perlakuan dan kontrol menunjukkan adanya beda nyata, pada jumlah daun kangkung pada 2 minggu penanaman. Hal ini disebabkan tersedianya nutrisi pada awal pertumbuhan tanaman kangkung dari perlakuan pupuk kandang dan kompos. Tanaman pada perlakuan nutrisi dengan kadar nitrogen lebih tinggi memiliki daun relatif lebih banyak. Pemberian nutrisi dengan kadar nitrogen tinggi mempengaruhi tinggi tanaman tetapi juga berpengaruh terhadap banyaknya daun pertanaman.

\section{Luas Daun}

Dari hasil Analisis Varian terhadap pertumbuhan Luas Daun anggrek Dendrobium setelah penanaman selama 12 minggu nilai signifikansi $0,000<0,05$. Pada perlakuan B/K.1/2 dihasilkan pertumbuhan paling bagus untuk Luas Daun $\left(26,800 \mathrm{~cm}^{2}\right)$ dan hasil uji lanjut DMRT terdapat perbedaan pada pertumbuhan Luas Daun pada perlakuan $\mathrm{B} / \mathrm{K} .1 / 2$ dengan perlakuan $\mathrm{A} / \mathrm{K} .0$, C/K.1/3, dan D/K.1/4, dan antar perlakuan A/K.0, C/K.1/3, dan D/K.1/4, tidak terdapat perbedaan. Perbedaan Panjang Daun ini terjadi kemungkinan karena kompos kulit kacang yang diberikan pada media tumbuh anggrek Dendrobium tersebut. Dan hal ini sesuai dengan hasil penelitian dari Iga Noviarti, Mulyati, dan Lince Meriko (2015), Kulit kacang tanah digunakan sebagai pupuk Bokashi pada produksi tanaman Buncis (Phaseolus vulgaris L) dimana pemberian bokashi kulit kacang tanah dapat meningkatkan produksi buncis yaitu pada jumlah polong buncis.

Perlakuan B/K.1/2 hasil pertumbuhan terbaik pada Luas Daun, dimana Luas Daun merupakan indikator kesuburan tanaman dari hasil Fotosintesa, dan pada Fotosintewsa sangat dibutuhkan nutrisi atau pupuk pada tanaman. Nitrogen berperan untuk sintesis protein untuk pertumbuhan tanaman termasuk pertumbuhan daun, bila tanaman kekurangan $\mathrm{N}$ menyebabkan pertumbuhan terhambat. Peran utama nitrogen bagi tanaman yaitu merangsang pertumbuhan seluruh tanaman terutama batang, cabang, dan daun. Pada pertumbuhan vegetatif tanaman yang ditunjukkan dengan pertambahan panjang, salah satu unsur hara yang berperan adalah nitrogen $(\mathrm{N})$. Nitrogen memacu pertumbuhan pada vase vegetatif terutama daun dan batang (Sayekti, R. S, at all. 2016), sehingga wajar jika perlakuan B/K.1/2 yang mengandung paling banyak unsur $\mathrm{N}, \mathrm{P}$, dan, $\mathrm{K}$ dapat menghasilkan pertumbuhan Luas Daun paling baik, Setiawan (2005) menjelaskan bahwa pupuk buatan limbah kacang tanah mengandung unsur hara makro yakni N, P, dan K. Ketiga unsur inilah yang paling banyak dibutuhkan oleh tanaman, karena masing-masing mempunyai fungsi bagi pertumbuhan tanaman. Kulit 
kacang mengandung banyak mineral, seperti kalsium, fosfor, potasium, iron, sodium, mangan, zink. yang sangat bermanfaat bagi tanaman (Nisrina, 2013). Hasil penelitian Ardola Rigen Prasetyo Utomo (2015) bahwa dalam pupuk organik cair dari kulit kacang tanah dan rumen sapi dengan penambahan jamur Trichoderma sp. mempunyai kandungan makronutrien ( $\mathrm{N}, \mathrm{P}$ dan $\mathrm{K}$ ) yang tinggi.

\section{Jumlah Anakan}

Dari hasil Analisis Varian (ANAVA) terhadap pertumbuhan Jumlah Anakan anggrek Dendrobium setelah penanaman selama 12 minggu nilai signifikansi $0,831>0,05$ dan hasil uji lanjut DMRT pada perlakuan A/K.0, B/K.1/2, C/K.1/3, dan D/K.1/4 tidak terdapat perbedaan yang signifikan, namun secara matematik terdapat perbedaan meskipun hanya kecil. Perbedaan pertumbuhan Jumlah Anakan terjadi kemungkinan karena kompos kulit kacang yang diberikan pada media tumbuh anggrek Dendrobium tersebut. Dan hal ini sesuai dengan hasil penelitian dari Iga Noviarti, Mulyati, dan Lince Meriko (2015), Kulit kacang tanah digunakan sebagai pupuk Bokashi pada produksi tanaman Buncis (Phaseolus vulgaris L) dimana pemberian bokashi kulit kacang tanah dapat meningkatkan produksi buncis yaitu pada jumlah polong buncis. Perbedaan yang kecil pada Jumlah Anakan kemungkinan karena perlakuan penanaman yang masih kurang lama sehingga ratarata tanaman anggrek hanya bertambah satu anakan, dari rata-rata dua anakan menjadi tiga anakan (perlakuan A/K.0 jumlah rata-rata anakan 3,1, B/K.1/2 jumlah rata-rataanakan 3,3, C/K.1/3 jumlah rata-rata anakan 3,2, dan D/K.1/4 jumlah rata-rata anakan 3, dan hasil Jumlah Anakan terbaik pada perlakuan $\mathrm{B} / \mathrm{K} .1 / 2$ yaitu 3,3 .

\section{Berat Basah}

Dari hasil Analisis Varian terhadap Berat Basah anggrek Dendrobium setelah penanaman selama 12 minggu nilai signifikansi $0,000<0,05$ Pada perlakuan B/K.1/2 dihasilkan pertumbuhan paling bagus untuk Berat Basah (24,1900 gram) dan hasil uji lanjut DMRT terdapat perbedaan pada pertumbuhan Luas Daun pada perlakuan B/K.1/2 dengan perlakuan A/K.0, C/K.1/3, dan D/K.1/4, dan perlakuan $\mathrm{C} / \mathrm{K} .1 / 3$ berbeda dengan $\mathrm{D} / \mathrm{K} .1 / 4$, dan A/K.0 pada Berat Basah tanaman, namun perlakuan D/K.1/4 dengan A/K.0 tidak terdapat perbedaan pada Berat Basah. Perbedaan Berat Basah tanaman anggrek Dendrobium ini terjadi kemungkinan karena kompos kulit kacang yang diberikan pada media tumbuh anggrek Dendrobium tersebut. Dan hal ini sesuai dengan hasil penelitian dari Iga Noviarti, Mulyati, dan Lince Meriko (2015), Kulit kacang tanah digunakan sebagai pupuk Bokashi pada produksi tanaman Buncis (Phaseolus vulgaris $L)$ dimana pemberian bokashi kulit kacang tanah dapat meningkatkan produksi buncis yaitu pada jumlah polong buncis.

Perlakuan B/K.1/2 hasil pertumbuhan terbaik pada Berat Basah, dimana Berat Basah tanaman merupakan indikator kesuburan tanaman dari hasil Fotosintesa, dan pada Fotosintewsa sangat dibutuhkan nutrisi atau pupuk pada tanaman. Peran utama nitrogen bagi tanaman yaitu merangsang pertumbuhan seluruh tanaman terutama batang, cabang, dan daun. Pada pertumbuhan vegetatif tanaman yang ditunjukkan dengan pertambahan panjang, salah satu unsur hara yang berperan adalah nitrogen $(\mathrm{N})$. Nitrogen memacu pertumbuhan pada vase vegetatif terutama daun dan batang (Sayekti, R. $S$, at all. 2016), sehingga wajar jika perlakuan $\mathrm{B} / \mathrm{K} .1 / 2$ yang mengandung paling banyak unsur $\mathrm{N}$, $\mathrm{P}$, dan, $\mathrm{K}$ dapat menghasilkan Berat Basah paling baik, Setiawan (2005) menjelaskan bahwa pupuk buatan limbah kacang tanah mengandung unsur hara makro yakni N, P, dan K. Ketiga unsur inilah yang paling banyak dibutuhkan oleh tanaman, karena masing-masing mempunyai fungsi bagi pertumbuhan tanaman. Kulit kacang mengandung banyak mineral, seperti kalsium, fosfor, potasium, iron, sodium, mangan, zink. yang sangat bermanfaat bagi tanaman (Nisrina, 2013). Hasil penelitian Ardola Rigen Prasetyo Utomo (2015) bahwa dalam pupuk organik cair dari kulit kacang tanah dan rumen sapi dengan penambahan jamur Trichoderma sp. mempunyai kandungan makronutrien $(\mathrm{N}, \mathrm{P}$ dan K) yang tinggi. 


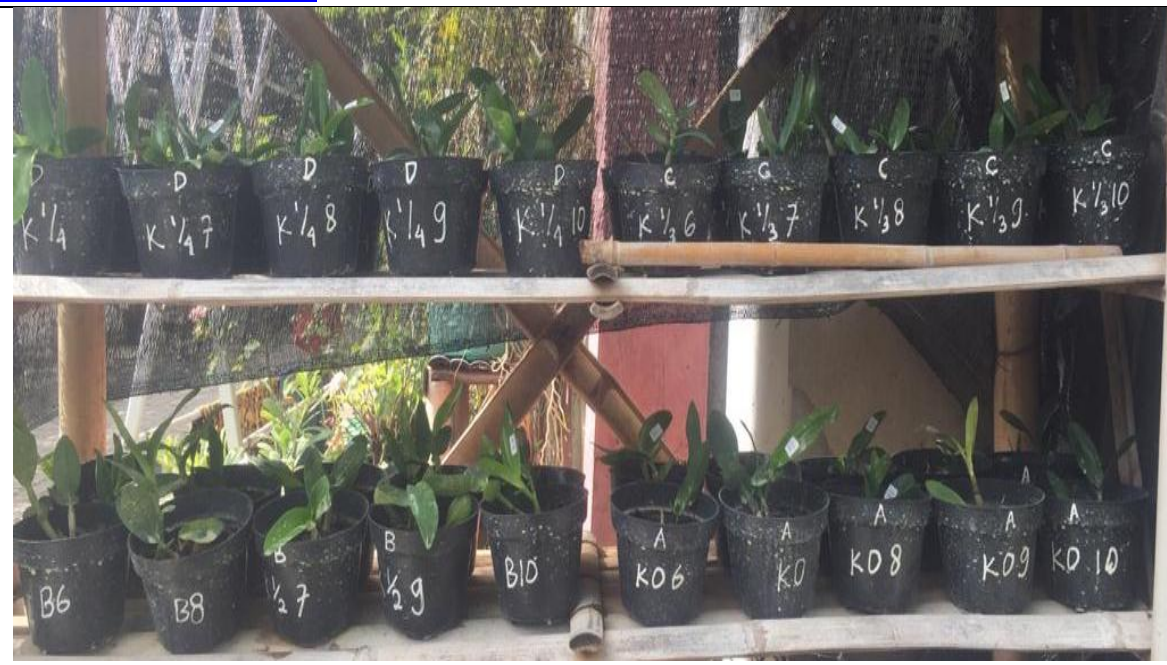

Kondisi anggrek setelah 12 minggu penanaman

(19 Desember 2020)

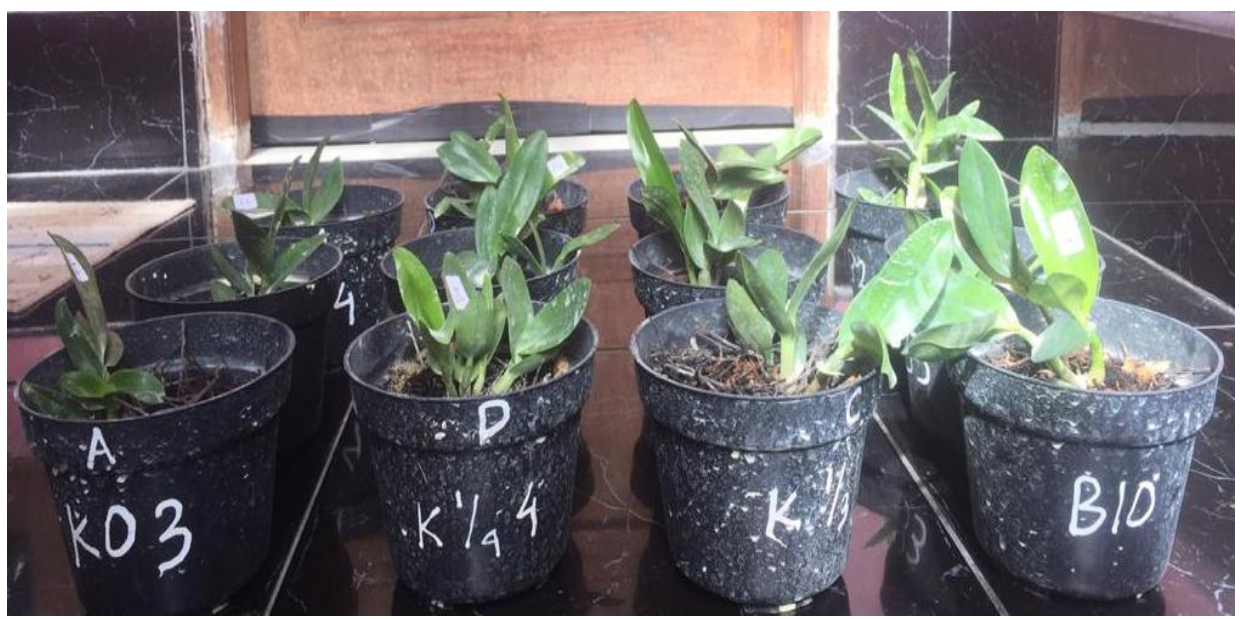

Perbandingan anggrek pada 4 perlakuan setelah 12 minggu penanaman

\section{Kesimpulan}

Dari hasil penelitian dapat disimpulkan bahwa Variasi campuran kompos kulit kacang tanah pada media tumbuh memberikan pengaruh yang nyata terhadap pertumbuhan anggrek Dendrobium pada empat 4 parameter pertumbuhan yang diamati (Panjang Daun, Jumlah Daun, Luas Daun, dan Berat Basah). Sedang untuk Jumlah anakan terdapat perbedaan pengaruh, meskipun perbedaan tersebut tidak signifikan. Perlakuan campuran kompos B/K.1/2 atau dengan perbandingan 1:1 memberikan pengaruh paling baik pada semua parameter pertumbuhan yang diamati (Panjang Daun, Jumlah Daun, Luas Daun, Jumlah Anakan, serta Berat Basah). Masih perlu dikembangkan penelitian lanjutan tentang kompos kulit kacang tanah sebagai campuran media tumbuh, karena selain dapat menekan biaya media tumbuh juga dapat menekan biaya untuk pembelian pupuk, karena kompos kulit kacang tanah banyak mengandung unsur N, P, dan K. Pemberian campuran kompos kulit kacang tanah pada media tumbuh dapat menekan biaya perawatan, sehingga dapat meningkatkan keuntungan bagi kolektor dan pengusaha anggrek Dendrobium.

\section{Ucapan Terima Kasih}

Ucapan terima kasih saya sampaikan kepada dekan Fakultas Keguruan dan Ilmu Pendidikan serta ketua LPPM Universitas Veteran Bangun Nusantara Sukoharjo yang telah memberikan ijin dalam 
penelitian ini, serta para mahasiswa yang telah membantu pelaksanaan penelitian dari awal sampai akhir. Penelitian ini dilaksanakan dengan dana APBU Universitas Veteran Bangun Nusantara Sukoharjo tahun anggaran 2019/2020 sebesar 10 juta rupiah.

\section{Referensi}

Andalasari, Tri Dewi, Yafisham \& Nuraini (2014). Respon Pertumbuhan Anggrek Dendrobium Terhadap Jenis Media Tanam Dan Pupuk Daun. Jurnal Penelitian Pertanian Terapan 14 (1): $\quad 76-82 \ldots \ldots . . \quad$ ISSN $1410-5020$. URL.https://jurnal.polinela.ac.id/index.php/J PPT/article/viewFile/145/115 DOI: http://dx.doi.org/10.25181/jppt.v14i1.145

Anwar, Hidayat (2014). Statistikian .Penjelasan dan Teori Uji Kruskal Wallis $H$. DOI:https://www.statistikian.com/2014/07/uj i-kruskallwallish.html\#: :text=Uji\%20 Kruskal\%20Wallis\%

Bakrie, Azlina Heryanti (2008). Pertumbuhan Vegetatif Tanaman Anggrek Dendrobium (Dendrobium Sp.) Pada Aplikasi Zeolit Sebagai Campuran Media Tanam Dan Pupuk Pelengkap Cair. Jurnal Zeolit Indonesia Vol 7 No. 1. Mei 2008. 53-60 Hlm. URL. http://journals.itb.ac.id/index.php/jzi. Doi. https://media.neliti.com/media/publications/2 19788-vegetatif-growth-of-dendrobium orchid-de.pdf

Dahlan \& Darmansyah (2011). Jurnal Agrisistem, Desember 2011, Vol. 7 No. 2 Issn 18584330 Pemanfaatan Kulit Kacang Tanah Sebagai Pupuk Organik Pada Kacang Tanah. Sekolah Tinggi Penyuluhan Pertanian (STPP) Gowa 2BP4K Kab. Pangkep

Departemen Pertanian (2005). "Prospek dan Arah Pengembangan Agribisnis Anggrek".DOI: http://www.litbang.deptan.go.id.

Iga Noviarti, Mulyati, \& Lince Meriko (2015). Artikel Ilmiah Efektifitas Bokashi Kulit Kacang Tanah ( Arachis hypogea L.) Terhadap Produksi Tanaman Buncis ( Phaseolus vulgaris L.). Program Studi Pendidikan Biologi
Sekolah Tinggi Keguruan Dan Ilmu Pendidikan (Stkip) Pgri Sumatera Barat Padang. DOI: file:///C:/Users/Ibu\%20Nur/ Downloads/ efektifitas-bokashi-kulit-kacang tanah- arachis- hypogea-l-terhadap-produksitanaman-buncis-phaseolus-vulgaris-l.pdf

Hanik, Nur Rokhimah (2007). Pengaruh Variasi Media dan Pemberian Start Vitamin BI Terhadap Pertumbuhan Anggrek bulan Phalaenopsis amabilis. Thesis. Agronomi UNS Surakarta.

Hanik, Nur Rokhimah, Sri Harsono, \& Anwari Adi Nugroho (2020). Selection of Peanut Skin as a Growing Medium for Moon Orchid (Phalaenopsis amabilis). Jurnal Biologi Tropis, 20 (2): 237 - 244 DOI: http://dx.doi.org/10.29303/jbt.v20i2.1896 238 $\underline{\mathrm{h}}$

Hanum, Siti Fatimah, Hendriyani, Erma \& Kurniawan, Agung (2014). Daerah Penyebaran, Populasi Dan Habitat Paku Pohon (Cyathea Spp. Dan Dicksonia Sp.) Di Bali. Indonesia Forest Rehabilitation Journal, 2. (2), September 2014: 111-122 URL: $\quad$ Http://Ejournal.FordaMof.Org/Ejournal-Litbang/Index.Php/IFRJ/

Herliana, O. E. Rokhminarsi, S. Mardini \& M. Jannah (2018). Pengaruh jenis media tanam dan aplikasi pupuk hayati mikoriza terhadap pertumbuhan, pembungaan dan infeksi mikoriza pada tanaman anggrek Dendrobium sp. Jurnal Kultivasi, 17(1) Maret 2018. URL: http://jurnal.unpad.ac.id/kultivasi/article/vie wFile/15774/7789

Indrasti, Nastiti Siswi \& Elia, Rio Reyno. (2004). Pengembangan Media Tumbuh Anggrek Dengan Menggunakan Kompos. Jurnal. Teknologi Industri Pertanian. 14(2), 40-50 URL: https://journal.ipb ac.id/ index.php/jurnaltin/issue/view/662

Irdhawati Irdhawati1, Alling Andini, \& Made Arsa1 (2016) Daya Serap Kulit Kacang Tanah Teraktivasi Asam Basa Dalam Menyerap Ion Fosfat Secara Bath Dengan Metode Bath. Journal Kimia Riset, 1 (1): 52 - 57 ISSN: 
Hanik, NR. et al., (2021). Jurnal Biologi Tropis, 21 (1): 237 - 247 DOI: http://dx.doi.org/10.29303/jbt.v21i1.2465

2528-0422

http://id.portalgaruda.org/index.php?ref= browse $\&$ mod $=$ viewarticle $\&$ article $=467325$

Kartana, Alam Syarif Nizar (2017). Uji Berbagai Media Tanam Dalam Meningkatkan Pertumbuhan Bibit Anggrek Bulan Yang Berasal Dari Alam. Jurnal Publikasi Informasi Pertanian. 13 (24): 20-26. URL: .http://jurnal.unka.ac.id/index.php/piper/articl e/view/72/163

Parnata, A.Y. (2005). Panduan Budidaya dan Perawatan Anggrek. Cetakan Pertama. PT. Agromedia Pustaka. Jakarta.

Peraturan Menteri Lingkungan Hidup Dan Kehutanan Republik Indonesia Nomor P.92/Menlhk/ Setjen/Kum.1/8/2018)

Mosooli, Chandra, Marthen T. Lasut, J. I. Kalangi, \& Jos Singgano (2016). Pengaruh Media Tumbuh Kompos Terhadap Pertumbuhan Bibit Jabon Merah (Anthocephalus Macropyllus). Jurnal Ilmiah Fakultas Pertanian. Universitas Samratulangi URL. https://ejournal.unsrat.ac.id/ index.php/ cocos/article/viewFile/12301/11881

Nina Solvia (2010). Budidaya Anggrek. Balithi. (Balai Penelitian Tanaman Hias). DOI: http://balithi.litbang.pertanian.go.id/berita144-budidaya-anggrek.html

Nisrina (2013). Tempo.Co. Sabtu 6 Juli 2013. Meneliti kulit Kacang Tanah Nisrina Ciptakan 3 Produk. DOI: https://tekno.tempo.co/read/493994/menelitikulit-kacang-nisrina-ciptakan-3produk/full\&view $=$ ok

Rachman, Faisal (2019). Cara Menanam Dan Merawat Bunga Anggrek Dendrobium Supaya Cepat Tumbuh. DOI: https:// magersena. blogspot.com/2019/08/cara-menanam-dan$\underline{\text { merawat-anggek-dendrobium. html }}$

Salisbury F. B \& Ross C. W. (1995). Fisiologi Tumbuhan 2 (Terjemahan). Bandung ITB. $173 \mathrm{p}$.
Sandra A. Aziz, Krisantini, Winarso D. Widodo \& Aris Munandar (2019). . Pemanfaatan Sekam, Serbuk Gergaji, Kulit Kayu Dan Kulit Kacang Tanah Sebagai Media Tumbuh Tanaman Dalam Wadah. Buletin Agr. XXI (1). 2019 DOI: file:///d:/penlt\%20kk\%202019/ Studi Pemanfaatan _Sekam_Serbuk_Gergaji_K.pdf.

Sayekti, R. S., Prayitno, \& D, Indradewa (2016). Pengaruh Pemanfaatan Pupuk Kandang dan Kompos terhadap Pertumbuhan Kangkung (Ipomea retans) dan Lele Dumbo (Clarias gariepinus) pada sistem Akuaponik http://ejurnal.bppt.go.id/index.php/JTL/issue/ view/107

Setiawan, H \& Setiawan, L. (2004). Merawat Phalaenopsis. Jakarta. Penebar Swadaya. 72 p.

Setiawan, H. (2005). Usaha Pembesaran Anggrek. Cetakan 4. Penebar Swadaya.Jakarta. 88 p.

Sitompul, S. M \& Guritno, Bambang (1995). Analisis Pertumbuhan Tanaman.Yogyakarta. Gadjah Mada University Press. 407 p.

S. Tuhuteru, M. L. Hehanussa, \& S.H.T. Raharjo (2012). Pertumbuhan Dandan Perkembangan Anggrek Dendrobium Anosmum Pada Media Kultur In Vitro Dengan Beberapa Konsentrasi Air Kelapa. Jurnal Agrologia, 1 (1), April 2012, (1-12) URL: https://ejournal.unpatti.ac.id/ ppr_agrologia.php?Hlm DOI: .https://ejournal.unpatti.ac.id/ ppr_agrologia. php?.jrnl nm=Agrologia

Tarigan, Henny Meita (2009) Pengaruh Beberapa Media Tanam dan Intensitas Pemupukan terhadap Pertumbuhan Anggrek (Oncidium golden shower).Skripsi. Departemen Ilmu Tanah Fakultas Pertanian. Universitas Sumatara Utara. Medan DOI: http://repository.usu.ac.id/bitstream/handle/ 123456789/7772/10E00211.pdf?sequence $=1$ \&isAllowed $=\mathrm{y}$ 
Hanik, NR. et al., (2021). Jurnal Biologi Tropis, 21 (1): 237 - 247 DOI: http://dx.doi.org/10.29303/jbt.v21i1.2465

Trivedi, Nikhilesh S., .Kharkar, Rhushikesh A \& Mandavgane Sachin A. (2019). 2,4 Dichlorophenoxyacetic acid adsorption on adsorbent prepared from groundnut shell: Effect of preparation conditions on equilibrium adsorption capacity. Arabian Journal of Chemistry12 (8): 4541-4549. DOI: $\quad$ https://www.sciencedirect.com /journal/ arabian-journal-of-chemistry/vol/ $\underline{12 / \text { issue/8 }}$

Utomo, Ardola Rigen Prasetyo (2015). Pemanfaatan Kulit Kacang Tanah Danrumen Sapi Untuk Pembuatan Pupuk Organik Cair Dengan Penambahan Jamur Trichoderma (Trichoderma Sp.)Skripsi. Program Studi Pendidikan Biologi. Fakultas Keguruan Dan Ilmu Pendidikan. Universitas Muhammadiyah Surakarta. DOI: .eprints.ums.ac.id/archive/etd/33431/1/3

Widiastoety, Dyah (2004). Bertanam Anggrek. Penebar Swadaya. Jakarta. Hlm.76 